\title{
Isolation and identification of Bifidobacterium spp. from infant intestinal tract
}

\author{
Do Thi Men', Pham Thi Le ${ }^{1}$, Tran Van Tuan ${ }^{1}$ \\ Ninh Thị Tuyet Lan², Nguyen Thi Minh Huyen* \\ ${ }^{1}$ University of Science, Vietnam National University, Hanoi \\ ${ }^{2}$ Institute of Biotechnology, Vietnam Academy of Science and Technology, Hanoi
} (Received: 05/03/2020; Accepted: 30/06/2020)

\section{Abstract}

As one of the probiotic bacteria, Bifidobacterium is supplemented in the food industry such as in milk and yogurt. The advantageous impact of these bacteria on human health was reported. However, in Vietnam, the supplement of these bacteria as a probiotic source to the food was not much in the food industry. In our experiment, Bifidobacterium was isolated from a feces sample of 7 days-child which only had mother milk. The bacteria isolated from infant intestinal tract was Bifidobacterium infantis (B. infantis, closest to Bifidobacterium longum ssp. infantis strain Bi-26 with gene bank accession CP054425.1). The techniques to identify these bacteria were MALDI Biotyper, PCR, and sequencing. Our study is the first to isolate Bifidobacterium infantis in Vietnam. This experiment is original for further study of the characters of these bacteria to apply them in our daily life.

Keywords: Bifidobacterium, isolation, identification, intestinal tract.

\section{INTRODUCTION}

Bifidobacterium is a genus of Gram-positive, nonmotile, often branched anaerobic bacteria. They live in the gastrointestinal tract, vagina, and mouth of mammals, including humans. The uses of Bifidobacterium as probiotics are more and more popular all over the world. They are believed to have positive effects on human health [9]. Supplement of these bacterial strain into food has been used in food industry [10]. The bacteria cannot colonize the host themselves, therefore taken regularly for the benefits they confer can be accrued daily is necessary. The main effects of probiotic action were on infectious diarrhea and antibiotic-associated diarrhea, especially necessary in case of children who have been taken antibiotics to recover the good intestinal bacteria. The major mechanisms of action of probiotics are as following: (1) Enhancement of the epithelial barrier; (2) Increased adhesion to intestinal mucosa; (3) Inhibition of pathogen adhesion; (4) Competitive exclusion of pathogenic microorganisms; (5) Production of anti-microorganism substances; and (6) Modulation of the immune system [11]. Bifidobacterium was found mainly inhabitant in the infant gut. However at 2-year-olds, the strains were no longer detectable, may be due to the competition within the ecosystem over time [12]. These improved that supplement of these bacteria as probiotic regularly is necessary to keep healthy gastrointestinal tract. In our gut system, Bifidobacterium help to digest dietary fiber, prevent infection, and produce vitamins and other important chemicals. Bifidobacterium is believed to prevent and/or treat colorectal cancer in which it may reduce the occurrence of carcinogen-induced cancerous cells in mice. The treatment of diarrhea using Bifidobacterium

\footnotetext{
*Corresponding author:Tel:0947479978_Email:nmhuyen09@gmail.com
} 
was also successful due to the inhibition of rotavirus [13]. With many benefits that Bifidobacterium brings to human health, study and use of Bifidobacterium in our daily life is very important. There were several studies in Vietnam to isolate of Bifidobacterium [16-17]. However, this study is first isolated and identified the Bifidobacterium infantis which present in an infant intestinal tract in Vietnam. The study is the first step of the characterization of these probiotic bacteria.

\section{MATERIALS AND METHODS}

\subsection{Materials}

Bacteria were isolated from feces samples of a seven days old-infant which only drink mother's milk. This infant was born in Hanoi Obstetrics and Gynecology Hospital and from a Hanoi's mother.

Modified VL-G medium (BSM) following Ryuichiro Tanaka and Masahiko Mutai report [14] was prepared as following recipe: $7.5 \mathrm{~mL}$ of Sol. I $\left(0.1 \% \mathrm{~K}_{2} \mathrm{HPO}_{4}\right) ; 7.5 \mathrm{~mL}$ of Sol II $(0.6 \%$ $\left.\mathrm{KH}_{2} \mathrm{PO}_{4}, 1.2 \%\left(\mathrm{NH}_{4}\right)_{2} \mathrm{SO}_{4}, 1.2 \% \mathrm{NaCl}, 0.12 \% \mathrm{MgSO}_{4} .7 \mathrm{H}_{2} \mathrm{O}, 0.12 \% \mathrm{CaCl}_{2} .2 \mathrm{H}_{2} \mathrm{O}\right) ; 0.1 \mathrm{~mL}$ of $0.1 \%$ resaruzin; $1 \mathrm{~g}$ trypticase; $0.5 \mathrm{~g}$ yeast extract; $0.2 \mathrm{~g}$ meat extract; $0.5 \mathrm{~g}$ glucose; $5 \mathrm{~mL}$ of $8 \% \mathrm{Na}_{2} \mathrm{CO}_{3} ; 1 \mathrm{~mL}$ of $3 \%$ cystein $-\mathrm{HCl} ; 79 \mathrm{~mL} \mathrm{H} \mathrm{H}_{2} \mathrm{O}$ for enough $100 \mathrm{~mL}$ of medium, adjust $\mathrm{pH}$ to 6.8 and autoclave at $121^{\circ} \mathrm{C}$ in $15 \mathrm{~min}$.

DNA purification Kit was purchased from Thermo science; Ez PCR Mix was purchased from Phusa Biochem, Vietnam. The $1 \mathrm{~Kb}$ DNA ladder was purchased from Thermo Scientific. Other chemical reagents used in this study such as EDTA, Tris-HCl, PBS, lysozyme, acetic acid, agarose, medium components, etc. were purchased from well-known companies at molecular biology grade.

Primers for PCR were designed following Matsuki et al., 1998 and 1999 [1-2] with a little modify. The primers were ordered from Phusa Biochem, Vietnam with the sequences shown in Table 1.

Table 1. PCR primer sequences for specific detection of Bifidobacterium

\begin{tabular}{|c|c|c|c|c|}
\hline Primer $^{a}$ & Sequences $\left(5^{\prime} \rightarrow 3^{\prime}\right)^{b}$ & $\begin{array}{c}\text { Product } \\
\text { size }\end{array}$ & $\begin{array}{c}\text { Target } \\
\text { Bifidobacterium }\end{array}$ & References \\
\hline BiBIF-1 & CAT GAT CGC ATG TGA TTG & \multirow{2}{*}{$278 \mathrm{bp}$} & \multirow{2}{*}{ B. bifidum } & \multirow{2}{*}{$\begin{array}{l}\text { Matsuki et } \\
\text { al., } 1998 \text { [1] }\end{array}$} \\
\hline BiBIF-2 & CCG AAG GCT TGC TCC CAA A & & & \\
\hline BiLON-1 & TTC CAG TTG ATC GCA TGG TC & \multirow{2}{*}{$831 \mathrm{bp}$} & \multirow{2}{*}{ B. longum } & \multirow{2}{*}{$\begin{array}{l}\text { Matsuki et } \\
\text { al., } 1999 \text { [2] }\end{array}$} \\
\hline BiLON-2 & GGG AAG CCG TAT CTC TAC GA & & & \\
\hline BiLON-1 & TTC CAG TTG ATC GCA TGG TC & \multirow{2}{*}{$828 \mathrm{bp}$} & \multirow{2}{*}{ B. infantis } & \multirow{2}{*}{$\begin{array}{l}\text { Matsuki et } \\
\text { al., } 1999 \text { [2] }\end{array}$} \\
\hline BiINF-2 & GGA AAC CCC ATC TCT GGG AT & & & \\
\hline
\end{tabular}

${ }^{a}$ Number 1 expressed for forward primers, number 2 expressed for reversed primers in a PCR reaction.

${ }^{\mathrm{b}}$ The source DNA sequences from $16 S \mathrm{rRNA}$ genes.

\subsection{Methods}

2.2.1. Isolation of bacterial from yogurt and feces samples

Bifidobacterium strains were isolated from feces of infant as following procedure: One 
gram of fresh feces was transferred into $15 \mathrm{~mL}$ falcon tube with $12 \mathrm{~mL}$ BSM. The mixture was vortex to homogenized and serial dilution was made. $0.2 \mathrm{~mL}$ of the suspension at appropriate dilution was plated with the BSM agar medium. All plates were incubated anaerobically at $37^{\circ} \mathrm{C}$ for 2 days using Oxoid gas box with anaerobic gasp. The separated colonies were picked and inoculated anaerobically in BSM medium for 2 days [14-15].

The cultures were preserved in BSM with 20\% of glycerol for long time storage.

\subsubsection{Morphology observation and gram staining}

Colonial morphology was observed by eyes and recorded with a camera. Cell morphology was observed by an optical microscope at the magnification of 1000 times in the oil immersion objective lens.

The cell staining was performed following gram staining protocol. Briefly as follow: appropriate cells amount was spread on a lamella; wait until completely dry in air or dry using gentle alcohol flame. Stain with crystal violet about 30 seconds to 1.0 minute; wash out all of un-stained dye with tap water. Add the iodine solution on the smear to cover it for about 30 seconds; wash out with tap water. Add ethanol (95\%) for 15 seconds and remove ethanol. Second, stain with fuchsine takes for 30 seconds to 1 minute. Wash slides with tap water until no color appears. Wait until completely dry and observe with a brightfield microscope.

\subsubsection{DNA extraction}

The cell was cultured at $37^{\circ} \mathrm{C}$ in Oxoid gas box under anaerobic condition for $48 \mathrm{~h}$. Cell was collected by centrifugation at $5.000 \mathrm{rpm}$ for 10 minutes. The culture medium was removed. The DNA purification was performed using Thermo Scientific GeneJET Genomic DNA Purification Kit, following the manufacturer's protocol for Gram positive bacteria. Briefly, harvest bacterial cell in a 1.5 or $2 \mathrm{~mL}$ centrifuge tube. Resuspended the pellet in $180 \mu \mathrm{L}$ of Gram-positive bacteria lysis buffer (20 mM Tris-HCl, $\mathrm{pH}=8.0,2 \mathrm{mM}$ EDTA, 1.2\% Triton $\mathrm{X}-100$, add lysozyme to $20 \mathrm{mg} / \mathrm{mL}$ immediately before use). Incubated for $30 \mathrm{~min}$ at $37^{\circ} \mathrm{C}$. Add $200 \mu \mathrm{L}$ of Lysis buffer and $20 \mu \mathrm{L}$ Proteinase $\mathrm{K}$ solution and mix. Incubated the sample at $56^{\circ} \mathrm{C}$ in shaking water bath about $30 \mathrm{~min}$. Add $20 \mu \mathrm{L}$ of RNase A solution, mix used by vortex and incubated the mixture for $10 \mathrm{~min}$ at RT. Add $400 \mu \mathrm{L}$ of $50 \%$ ethanol and mix. Transferred the lysate to column. Centrifuged at $6.000 \mathrm{~g}$ for $1 \mathrm{~min}$. Washed with $500 \mu \mathrm{L}$ of Wash Buffer I, centrifuged at $8.000 \mathrm{~g}$ for $1 \mathrm{~min}$. Washed with $500 \mu \mathrm{L}$ of Wash Buffer II, centrifuged at 12.000g for $3 \mathrm{~min}$. Transferred the column to new tube. Added $100 \mu \mathrm{L}$ or $200 \mu \mathrm{L}$ of Elution buffer to the column, incubated for $2 \mathrm{~min}$ at RT and centrifuge at $8.000 \mathrm{~g}$ for $1.0 \mathrm{~min}$. Discarded the column and store DNA at $-20^{\circ} \mathrm{C}$ until use. DNA quantity and purity was determined using spectrophotometer.

\subsubsection{PCR analysis}

PCR was performed using EZ PCR Mix (Phusa Biochem, Vietnam) following the manufacturer's manual. The mixture includes: $22.5 \mu \mathrm{L}$ of $1 \mathrm{x}$ PCR buffer, $0.5 \mu \mathrm{L}$ of 10 picomolar primers each, $0.5 \mu \mathrm{L}$ of DNA template, add remaining water to final volume of $25 \mu \mathrm{L}$. The PCR was performed on Applied Biosystems ${ }^{\circledR}$ Veriti ${ }^{\circledR}$ 96-Well Thermal Cycler (Applied Bioscience) with the following program: 1 , pre-denaturation $95^{\circ} \mathrm{C}$ for 3 minutes; 2, denaturation $95^{\circ} \mathrm{C}$ for 30 seconds; 3 , annealing $55^{\circ} \mathrm{C}$ for 30 seconds; and 4 , extension $72^{\circ} \mathrm{C} 50 \mathrm{sec}$; with a repeat from step 2 to step 4 for 30 cycles; final extension $72^{\circ} \mathrm{C}$ in 5 minutes. PCR products were confirmed by agarose-gel electrophoresis at 100 voltages in 30 minutes and visualized by UV visualizer. 


\subsubsection{DNA sequencing}

PCR products were sent to Sanger's sequencing at National Key Laboratory for Gene Technology, Institute of Biotechnology with both of forward and reverse sequencing. The results were analyzed using BioEdit software and Blast tool in NCBI website.

\subsubsection{Bacterial identification using MALDI biotype system}

MALDI TOF (Vitek MS) is a new technique to identify microorganisms with high accuracy. The microorganisms were identified using MALDI-TOF Mass Spectrometry to determine the unique protein fingerprint of an organism. The bacterial isolated from above were sent to identification using MALDI TOF at The National Institute for Food Control, Vietnam. The results were analyzed with the reference library provided by the manufacturer.

\section{RESULTS AND DISCUSSIONS}

\subsection{Isolation of Bifidobacterium from infant intestinal tract}

Infant after born seven days who only drink mother milk was the subject for this experiment because of during this time is the first transition to establish of gut microbiota in the life of the baby. In this stage, the dominance of gut microbiota is Bifidobacterium [5]. By using anaerobic condition with BSM medium for isolation, there are two types of colony appeared in the culture plate (Figure 4a). The first one had a white color, spread broadly on the surface of agar (the marks near black arrows) and the second one was also white, condense and completely immersed inside the agar (the marks near gray arrows). Size and shape of the colonies were various in the second case. Even though there are two types of colony; the bacteria growth in BSM liquid media has a similar size and shape (Figure 4b). They are rod shape, shiny and have no branch.

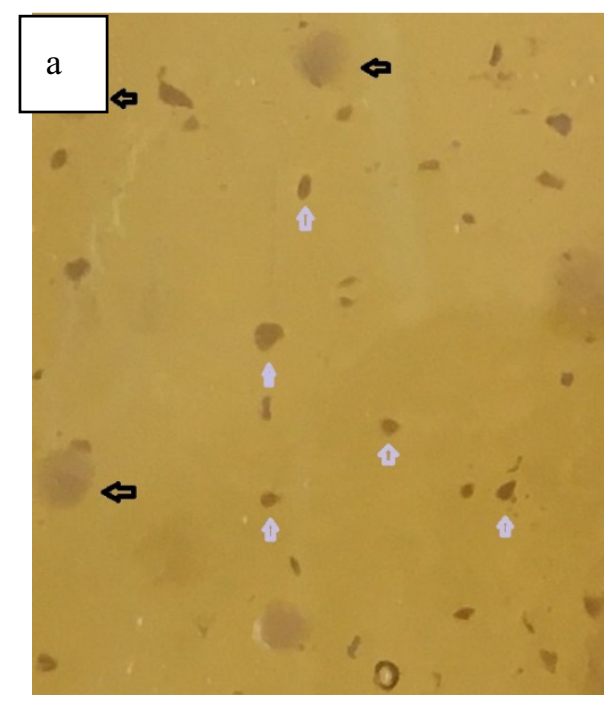

a. Separated single colony at $10^{-8}$ dilution in BSM medium

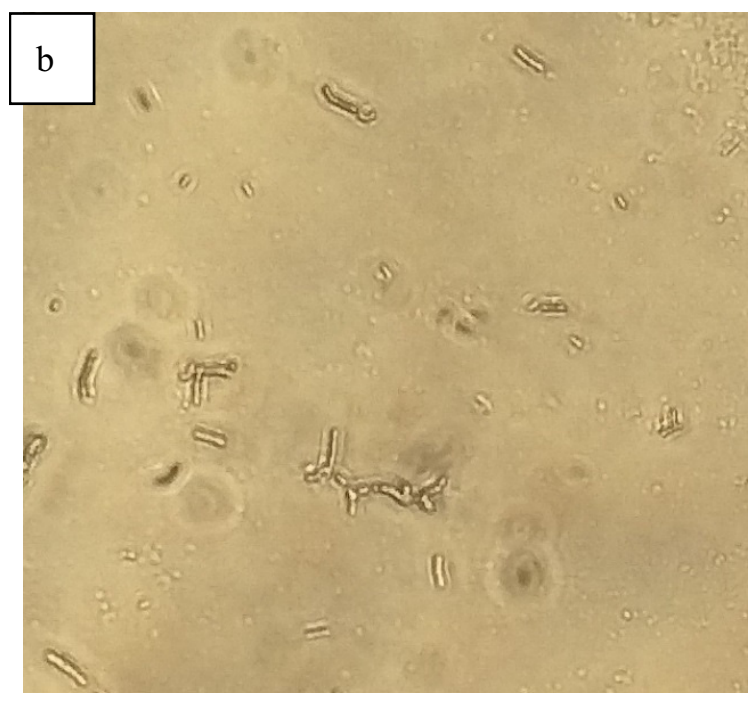

b. Microscope photo at 400 times magnification of bacteria in liquid culture

Figure 4. Strains isolated from infant intestinal tract

The Gram staining experiment revealed that they are Gram positive bacteria with the cells are completely stained purple, rod shape and can be single or chain (Figure 5). 


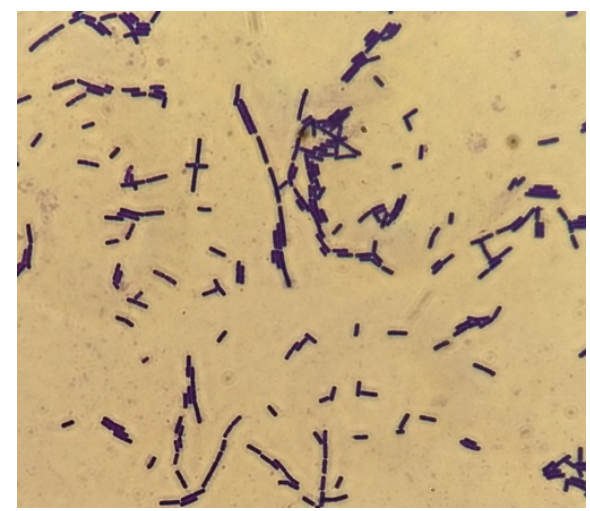

Figure 5. Gram staining of a colony isolated from infant intestinal tract

These two types of colonies were also identified by mass spectrometry (Table 3). Mass spectrometry outcomes also identified that both types of colony belonged to Bifidobacterium spp. with confidence values of 99.9 and 99.6, respectively.

Table 3. MALDI TOF result of isolated from infant intestinal tract

\begin{tabular}{|c|c|c|c|c|}
\hline No. & Strain name * & $\begin{array}{c}\text { Position of } \\
\text { colony }\end{array}$ & Organism name & $\begin{array}{c}\text { Confidence } \\
\text { value }\end{array}$ \\
\hline 1 & N7 & Inside of agar & Bifidobacterium spp. & 99.9 \\
\hline 2 & T4 & Surface of agar & Bifidobacterium spp. & 99.6 \\
\hline
\end{tabular}

* Name of strains were put to easy recognize by the student who directly done the experiment. $N$ is small colony, inside agar, $T$ is big colony on surface of agar, number after character is the order of colony was picked

Because of mass spectrometry results showed identification to genus but not species of bacteria, in this case, the PCR experiment for further identification of the bacteria was performed. In figure 6, lane 1 and 4 did not appear any band of PCR product, indicated that these two types of colonies do not belong to B. bifidum. Lane 2 and 5 appeared more than two bands and the size of the bands did not match to designed product for B. longum $(831 \mathrm{bp})$. Therefore, these bacteria were not belonging to $B$. longum as well. Lane 3 and 6 appeared clear bands at a position of about $800 \mathrm{bp}$ which suitable for the designed product of $B$. infantis ( $828 \mathrm{bp}$ ).

Figure 6. $P C R$ results of Bifidobacterium isolated from infant intestinal tract

M: 1kb Ladder; Lane 1, 4: specific PCR for B. bifidum (278 bp); Lane 2, 5: specific PCR for B. longum (831 bp), Lane 3, 6: specific PCR for B. infantis; (828 bp); Lane 1, 2, 3: colony isolated from surface of agar (T4); lane 4, 5, 6: colony isolated from inside agar (N7)

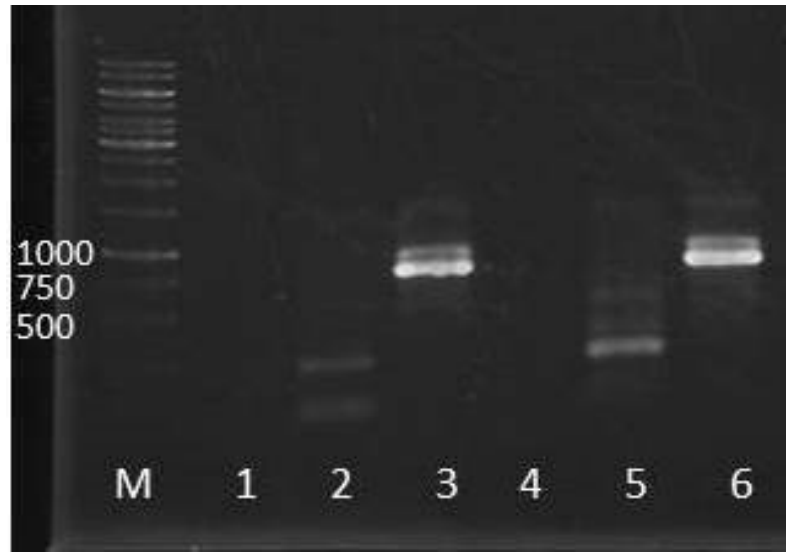


DNA sequencing of bands cut from lanes 3 and 6 (Table 4) was done with both forward and reverse chain of DNA. The result showed that they are both belonging to B. longum subspecies infantis strain Bi-26 with accession in gene bank CP054425.1. The result from PCR with specific primer to $B$. infantis was consistent with DNA sequencing result. Therefore, the bacteria isolated from infant intestinal tract under anaerobic condition with BSM medium were identified as B. longum subspecies infantis. The reference strain Bi-26 was originally isolated from infant feces which similar to our experiment [6]. These results one more time confirmed that the infant gut microbiota is abundant with Bifidobacterium especially B. infantis [5].

Table 4. BLAST result of isolated from infant intestinal tract

\begin{tabular}{|c|c|c|c|c|c|}
\hline No. & $\begin{array}{c}\text { Strain } \\
\text { name }\end{array}$ & \multicolumn{1}{|c|}{ Description } & $\begin{array}{c}\text { Total } \\
\text { score }\end{array}$ & $\begin{array}{c}\text { Percentage } \\
\text { of Identity }\end{array}$ & Accession \\
\hline 1 & N7 & $\begin{array}{l}\text { Bifidobacterium longum subsp. infantis } \\
\text { strain Bi-26 chromosome }\end{array}$ & 4443 & $99.83 \%$ & CP054425.1 \\
\hline 2 & $\mathrm{~T} 4$ & $\begin{array}{l}\text { Bifidobacterium longum subsp. infantis } \\
\text { strain Bi-26 chromosome }\end{array}$ & 3838 & $99.43 \%$ & CP054425.1 \\
\hline
\end{tabular}

* BLAST using NCBI blast tool, the results were the top identification which were highest total score of identification (https://blast.ncbi.nlm.nih.gov/Blast.cgi)

\section{CONCLUSION}

Bifidobacterium was isolated from infant feces. The identification of bacteria isolated from infant intestinal tract was most close to Bifidobacterium longum subsp. infantis strain Bi-26 with gene bank accession CP054425.1. These results will be original for further study to apply these bacteria to our life as a probiotic source which will be helpful for our health system.

\section{ACKNOWLEGMENTS}

This work was supported by Korea Institute of Science and Technology (KIST) under KIST School Partnership Funding 2020 to Nguyen Thi Minh Huyen.

\section{REFERENCES}

[1] T. Matsuki, K. Watanabe, R. Tanaka and H. Oyaizu, "Rapid identification of human intestinal bifidobacteria by $16 \mathrm{~S}$ rRNA-targeted species- and group-specific primers", FEMS Microbiology Letters, vol. 167, no.2, pp.113-121, 1998.

[2] T. Matsuki, K.Watanabe, R.Tanaka, M. Fukuda and H. Oyaizu, "Distribution of bifidobacterial species in human intestinal microflora examined with $16 \mathrm{~S}$ rRNAgene-targeted speciesspecific primers", Applied and Environmental Microbiology, vol. 65, no. 10, pp 4506-4512, 1999.

[3] B. Schulthess, G. V. Bloemberg, R. Zbinden, E. C. Böttger and M. Hombach, "Evaluation of the bruker MALDI biotyper for identification of gram-positive rods: Development of a diagnostic algorithm for the clinical laboratory", Journal of Clinical Microbiology, vol. 52, no. 4, pp. 1089 - 1097, 2014.

[4] MALDI Biotyper® CA System, Clinical Application for Identification of Microorganisms. 
BRUKER application.

[5] M. Tanaka and J. Nakayama, "Development of the gut microbiota in infancy and its impact on health in later life", Allergology International, vol. 66, no. 4, pp. 515-522, 2017.

[6] NCBI, Bifidobacterium longum subsp. infantis strain Bi-26 chromosome. GenBank: CP054425.1 [online]https://www.ncbi.nlm.nih.gov/nucleotide/CP054425.1?report=genbank\&log $\$=$ nuclalign\&blast rank=1\&RID $=\mathrm{G} 1 \mathrm{Y} 49 \mathrm{KXK014}$ ) [Accessed 30/3/2020].

[7] NCBI, Bifidobacterium longum Taxonomy ID: 216816 [online] https://www.ncbi.nlm.nih.gov/Taxonomy/Browser/wwwtax.cgi? $m o d e=i n f o \& i d=216816$ [Accessed 30/3/2020].

[8] Y. Li, M. Shan, Z. Zhu, X. Mao, M. Yan, Y. Chen, Q. Zhu, H. Li and B. Gu, "Application of MALDI-TOF MS to rapid identification of anaerobic bacteria", BMC Infectious Diseases, vol. 19, no.941, 2019.

[9] D. G. Hoover, "Bifidobacterium” Reference Module in Food Science: Encyclopedia of Food Microbiology (Second Edition), Pages 216-222, 2014

[10] K. C. Anukam and G. Reid, "Probiotics: 100 years (1907-2007) after Elie Metchnikoff's Observation", Communicating Current Research and Educational Topics and Trends in Applied Microbiology, pp. 466 - 474, 2007.

[11] M. Bermudez-Brito, J. P-D. S. Muñoz-Quezada, C. Gómez-Llorente, A. Gil, "Probiotic Mechanisms of Action", Annals of Nutrition \& Metabolism, vol. 61, no.2, pp. 160-174, 2012.

[12] M. Bazanella, T. V. Maier, T. Clavel, I. Lagkouvardos, M. Lucio, M. X. Maldonado-Gòmez, C. Autran, J. Walter, L. Bode, P. Schmitt-Kopplin and Dirk Haller, "Randomized controlled trial on the impact of early-life intervention with bifidobacteria on the healthy infant fecal microbiota and metabolome", The American Journal of Clinical Nutrition, vol. 106, no. 5, pp. 1274-86, 2017.

[13] A. O'Callaghan and D. van Sinderen, "Bifidobacteria and their role as members of the human gut microbiota", Frontiers in Microbiology, vol. 7, no. 925, 2016.

[14] R. Tanaka and M. Mutai, "Improved Medium for Selective Isolation and Enumeration of Bifidobacterium", Applied and Environmental Microbiology, vol. 40, no. 50, pp. 866-869, 1980.

[15] M. Hadadji, R. Benama, N. Saidi, D. E. Henni, and M. Kihal. "Identification of cultivable Bifidobacterium species isolated from breast-fed infants' feces in West-Algeria", African Journal of Biotechnology, Vol. 4 (5), pp. 422-430, 2005.

[16] Nguyen Thi Tuyen, Isolation of Bifidobacterium from several available environments, Study project 2012, Microbiology and Biotechnology Institute, Hanoi National University.

[17] Nguyen Hoang Tuan, Isolation and selection of Bifidobacteria, application in probiotics production, Thesis for Master of Science, 2017, Hanoi National University. 


\title{
Phân lập và định danh Bifidobacterium spp. từ dường tiêu hóa của trẻ so sinh
}

\author{
Đỗ Thị Mến ${ }^{1}$, Ninh Thị Tuyết Lan², Phạm Thị Lệ', Trần Văn Tuấn ${ }^{1}$ \\ Nguyễn Thị Minh Huyền² \\ ${ }^{1}$ Trường Đại học Khoa học Tụ nhiên, Đại học Quốc gia Hà Nội \\ ${ }^{2}$ Viện Công nghệ sinh học, Viện Hàn lâm Khoa học và Công nghệ Việt Nam
}

Tóm tắt

Là một trong những vi khuẩn probiotic, Bifidobacterium được sử dung để bổ sung vào thực phẩm trong công nghiệp thực phẩm như sữa và sữa chua. Những ảnh hưởng tốt của các vi khuẩn này đến sức khỏe con người đã được công bố. Tuy nhiên, ở Việt Nam, việc bổ sung những vi khuẩn này làm nguồn probiotic trong thực phẩm chưa được chú trọng trong ngành công nghiệp thực phẩm. Trong thí nghiệm này, Bifidobacterium được phân lập từ phân của trẻ bảy ngày tuổi chỉ bú sữa mẹ. Vi khuẩn phân lập được từ đường ruột của một trẻ 7 ngày tuổi tại Việt Nam là Bifidobacterium infantis (B. Infantis gần nhất là Bifidobacterium longum phân loài infantis chủng Bi-26, trình tự trên ngân hàng gene là CP054425.1). Các kỹ thuật được sử dụng để xác định các vi khuẩn này là MALDI Biotyper, PCR, và đọc trình tự gene. Nghiên cứu của chúng tôi là nghiên cứu đầu tiên phân lập được Bifidobacterium infantis tại Việt Nam. Đây là tiền đề cho các nghiên cứu tiếp theo để xác định đặc tính của các vi khuẩn này cho các ứng dụng vào cuộc sống con người.

Tù khóa: Bifidobacterium, phân lập, định danh, đường ruột. 